\title{
Programme of geochronology and isotope geochemistry in the Ammassalik region, South-East Greenland: outline and preliminary results
}

\author{
Feiko Kalsbeek and Paul N. Taylor
}

\begin{abstract}
Geological investigation of the Ammassalik region in the summer of 1986 included the collection of sample suites for isotopic dating. This report sets out the plans for future dating work, and presents some preliminary results on sample suites collected in 1986 and on earlier expeditions to the region. From the data now available it is clear that crustal evolution commenced during the Archaean and that further additions to the crust took place during early-to-mid-Proterozoic tectonothermal events. Some features of the geology of the Ammassalik region may be attributable to the collision of two Archaean continental blocks.
\end{abstract}

\section{Geological outline}

The Ammassalik region contains a Proterozoic mobile belt within which there has been extensive reworking of Archaean crust (Bridgwater \& Myers, 1979). Large areas consist of polyphase orthogneisses with complex deformation histories. At some localities it has been established that these rocks are of Archaean age (Bridgwater et al., 1977, 1978a; Pedersen \& Bridgwater, 1979).

Another prominent lithological component of the region is a suite of supracrustal rocks, dominated by metapelites with layers of marbles, quartzite and, locally, amphibolite (Hall et al., this volume - Supracrustals). The supracrustal units are sometimes more than a kilometre thick and occur in complex fold structures with the orthogneisses which enclose them (Chadwick \& Vasudev, this volume). Field observations have rarely provided unequivocal resolution of the age relationship between supracrustals and orthogneisses (Kalsbeek \& Nielsen, 1987); at a few localities, however, intrusive relationships show that some orthogneisses are younger than the supracrustal rocks (Chadwick \& Vasudev, this volume).

In the centre of the region, around Ammassalik town, the Ammassalik Intrusive Complex (AIC) comprises a suite of intrusive hypersthene-bearing dioritic to granodioritic rocks (Friend \& Nutman, this volume), and these have been dated by the U-Pb zircon method at $c$. $1885 \mathrm{Ma}$ (Hansen \& Kalsbeek, this volume). The AIC was emplaced into country rocks consisting mainly of metasediments, and caused widespread anatexis. The resulting anatexites are often rich in garnet, and constitute the 'garnet granite gneisses' of Wager (1934).

Basic dykes constitute a minor, though widespread, lithological component of the region. They are abundant in the orthogneisses, rare in the metasediments, and unknown in the AIC. From these observations, an early Proterozoic age for the emplacement of the dykes is considered probable. Many of the dykes suffered strong Proterozoic deformation and metamorphism, sometimes up to eclogite facies in areas lying further north than Ammassalik (Nutman \& Friend, this volume).

The youngest Precambrian rocks of the region are the post-tectonic suite of granites, diorites and, locally, gabbros. These form sharply cross-cutting plutons and have been dated at $c .1580$ Ma (Pedersen \& Bridgwater, 1979; Taylor et al., 1984).

\section{Sample collections}

Fig. 1 shows the main localities in the Ammassalik region at which sample collections have been made for geochronological work. Grey orthogneiss samples were collected at three sites, Nûk $\left(66^{\circ} 9.6^{\prime} \mathrm{N}, 37^{\circ} 33^{\prime} \mathrm{W}\right)$, near Tasîlârtik $\left(66^{\circ} 06.5^{\prime} \mathrm{N}, 38^{\circ} 05^{\prime} \mathrm{W}\right)$, and a locality in the Síportôq area at $65^{\circ} 35^{\prime} \mathrm{N}, 38^{\circ} 38^{\prime} \mathrm{W}$. These samples are generally poor in $\mathrm{Rb}$ and rich in $\mathrm{Sr}$ and are therefore not very suitable for $\mathrm{Rb}-\mathrm{Sr}$ isochron dating. To determine the age and origin of these rocks a programme of $\mathrm{Sm}-\mathrm{Nd}$ and $\mathrm{Pb}$ isotopic analysis is planned, together with U-Pb zircon work on selected samples. Garnetiferous mafic tonalite gneisses are common at Tasîlârtik, 


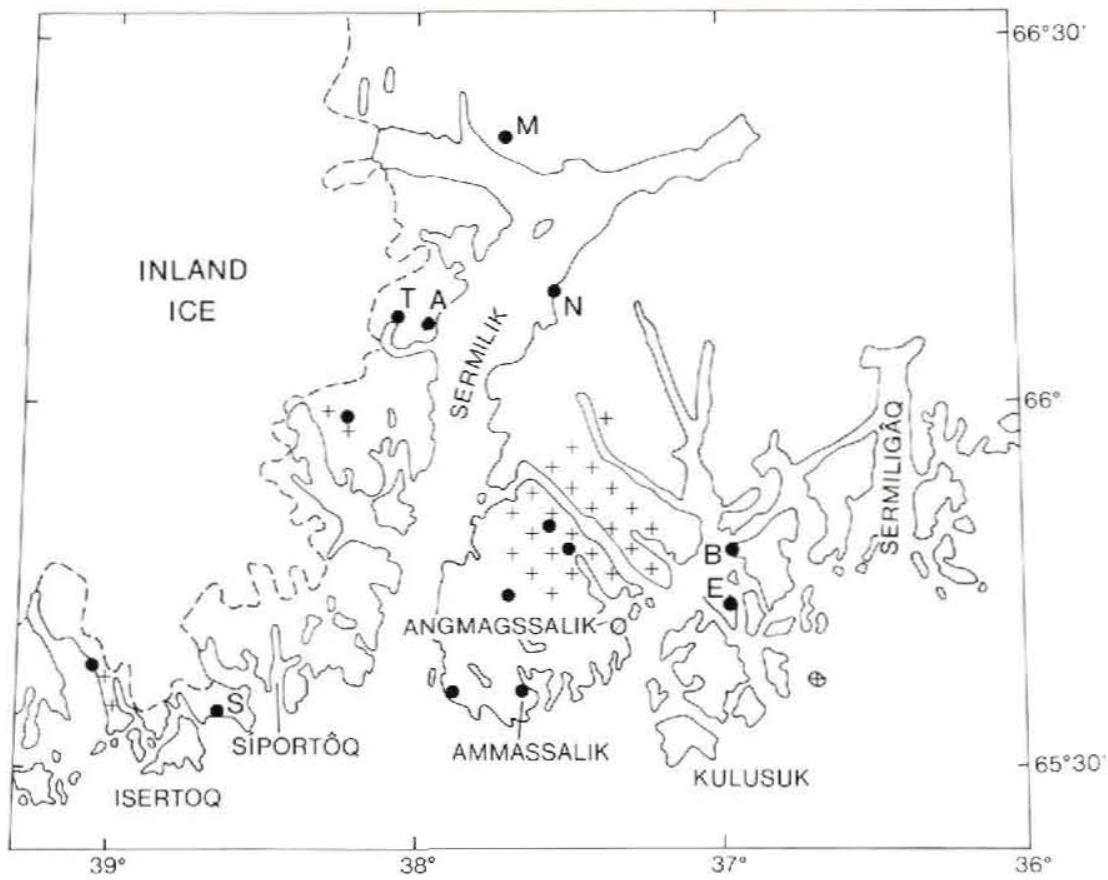

Fig. 1. Map of the Ammassalik region showing localities (dots) where collections for isotopic age determination were made. Crosses show the main outcrops of post-tectonic intrusions. $\mathrm{N}$ and A indicate the localities Nûk and Augpalugtoq where the metasediments were sampled for which preliminary $\mathrm{Rb}-\mathrm{Sr}$ isotope results are presented. S, T and B indicate the gneiss localities at Síportôq. Tasilârtik and Blokken for which we report preliminary $\mathrm{Sm}-\mathrm{Nd}$ results. $\mathrm{E}$ is the location of the dated eclogite dyke. $\mathrm{M}$ is the marble locality at the head of Sermilik. For a listing of the other localities see the text. and have also been sampled for dating. First results of $\mathrm{Sm}-\mathrm{Nd}$ analyses on these and other gneisses are presented below.

Pelitic metasediments were collected at Nûk $\left(66^{\circ} 9.6^{\prime} \mathrm{N}, 37^{\circ} 33^{\prime} \mathrm{W}\right)$, and at Augpalugtog $\left(66^{\circ} 06^{\prime} \mathrm{N}\right.$, $\left.37^{\circ} 56^{\prime} \mathrm{W}\right)$. These samples have a range of $\mathrm{Rb} / \mathrm{Sr}$ ratios favourable for isochron dating: results of $\mathrm{Rb}-\mathrm{Sr}$ and Sm-Nd work on these suites are presented below. In addition. a marble layer at a locality at the head of Sermilik $\left(66^{\circ} 22^{\prime} \mathrm{N}, 37^{\circ} 43^{\prime} \mathrm{W}\right)$ has been sampled for $\mathrm{Pb} / \mathrm{Pb}$ isochron dating by $\mathrm{J}$. C. Escher and R. P. Hall.

The Ammassalik Intrusive Complex has been sampled at the quarry in Ammassalik $\left(65^{\circ} 36.5^{\prime} \mathrm{N}\right.$, $\left.37^{\circ} 38^{\prime} \mathrm{W}\right)$. Results of U-Pb zircon dating are presented by Hansen \& Kalsbeek (this volume), and $\mathrm{Sm}-\mathrm{Nd}$ data for this unit are discussed below. The garnet granite gneisses which surround the AIC have been sampled on the coast west of Ammassalik town $\left(65^{\circ} 36.4^{\prime} \mathrm{N}\right.$, $37^{\circ} 53^{\prime} \mathrm{W}$ ).

Several sample suites were collected from the posttectonic plutons, with most samples from the valley of Kûgarmit avqutâ in the northeastern part of Angmagssalik $\varnothing$, around $65^{\circ} 50.3^{\prime} \mathrm{N}, 37^{\circ} 33^{\prime} \mathrm{W}$ and $65^{\circ} 49^{\prime} \mathrm{N}$, $37^{\circ} 31^{\prime} \mathrm{W}$. Other samples were collected at $65^{\circ} 37^{\prime} \mathrm{N}$. $39^{\circ} 02^{\prime} \mathrm{W} ; 65^{\circ} 46^{\prime} \mathrm{N} .37^{\circ} 41^{\prime} \mathrm{W}$ and $65^{\circ} 59^{\prime} \mathrm{N}, 38^{\circ} 15^{\prime} \mathrm{W}$. The age of the rocks is already well constrained by previous studies (see above), and the $\mathrm{Sr}, \mathrm{Nd}$ and $\mathrm{Pb}$ isotope geochemistry shows that the granites have incorporated major components of significantly older crustal material (Taylor et al., 1984). The new sample collections will be used principally to assess the petrogenetic relationships between the granites and the more mafic constituents of the post-tectonic intrusive suite.

\section{Results of isotopic investigations}

We report Sm-Nd results for a variety of rock samples from the Ammassalik region, and from the northern border zone of the mobile belt, where collections were made during the 1977 GGU South-East Greenland field season (Bridgwater et al., 1978b). All Sm-Nd results are here presented as $\mathrm{T}_{\mathrm{DD}}$ model ages, calculated according to the depleted mantle model of DePaolo (1981). Furthermore. we report $\mathrm{Rb}-\mathrm{Sr}$ results on two suites of metapelitic metasediments and $\mathrm{Pb} / \mathrm{Pb}$ results on a suite of marble samples.

\section{Gneisses}

Of the gneisses so far analysed from the area around Sermilik (fig. 1) only those from Nûk have yielded Archaean $\mathrm{T}_{1 \mathrm{M} \text { m }}$ model ages (3.02 and $2.98 \mathrm{Ga}$ ). A gneiss sample from Síportôq and two mafic tonalites from Tasîlârtik have model ages of c. $2.2 \mathrm{Ga}$, and these clearly document an episode of Proterozoic crustal growth in this area at or later than $2.2 \mathrm{Ga}$. Gneisses from the northern border zone of the mobile belt and beyond, as far north as Kangerdlugssuaq $\left(c, 68^{\circ} \mathrm{N}\right)$. yield $\mathrm{Sm}-\mathrm{Nd} \mathrm{T}_{\mathrm{DM}}$ model ages in the range $2.78 \mathrm{Ga}$ to $3.02 \mathrm{Ga}$. The Skjoldungen area along the coast to the 
South-West of the Ammassalik region $\left(c \cdot 63^{\circ} \mathrm{N}\right)$ has also yiejded exclusively Archaean $T_{D M}$ model ages ( 2.73 to $2.96 \mathrm{Ga}$, Kalsbeek \& Taylor, unpublished data).

A sample of the type Blokken Gneisses (B, fig. 1; cf. Dawes et al., this volume - Blokken) has a $\mathrm{T}_{\mathrm{DM}}$ model age of $3.01 \mathrm{Ga}$, in good accord with a U-Pb zircon age measurement of $2923_{-38}^{+61}$ Ma on the same sample (B. T. Hansen, personal communication, 1987). However. a $\mathrm{Pb} / \mathrm{Pb}$ isochron for this and other Blokken Gneiss samples yields a date of $2514_{112}^{+104} \mathrm{Ma}$. It is not yet clear how the whole-rock U-Pb systems have been resct.

\section{Metasediments}

Rb-Sr whole-rock isotope data for two suites of metasediment samples, from Nûk and Augpalugtoq (fig. 1), do not yield well-fitted isochrons but do define distinct linear arrays (fig. 2). Seven of the eight Nûk samples are garnetiferous metasediments and the best-lit line for these samples (MSWD 6.4) corresponds to a date of $1655 \pm 86 \mathrm{Ma}$ with an initial ${ }^{87} \mathrm{Sr} /{ }^{86} \mathrm{Sr}$ ratio of $0.729 \pm$ 0.003 . The other Nûk sample lacks garnet, is rich in pale green amphibole and may have a substantially different provenance: it plots far below the best-fit line for the Nûk metasediments in fig. 2. The fourteen samples from Augpalugtoq define a best-fit line (MSWD 8.6) yiclding a date of $1871 \pm 50 \mathrm{Ma}$ and initial ${ }^{87} \mathrm{Sr} /{ }^{86} \mathrm{Sr}$ $0.714 \pm 0.001$.

The three metasediment samples analysed for $\mathrm{Sm}-\mathrm{Nd}$ yield Archaean $\mathrm{T}_{\mathrm{DM}}$ model ages (Nûk: $2.84 \mathrm{Ga}$; Augpalugtog: 2.75 and $2.88 \mathrm{Ga}$ ), demonstrating that their sedimentary protoliths were derived substantidily from Archaean source rocks.

In fig. $2 \mathrm{c}$, back-extrapolation of $\mathrm{Sr}$ isotopic evolution lines to intersect the evolution line for Archaean gneisses in the region provides an estimate of the plausible depositional age for each of the metasediment suites. It would require substantial increase of average $\mathrm{Rb} / \mathrm{Sr}$ ratios of the metasediment suites during metamorphism to negate the conclusion that their sedimentary protoliths were deposited later than c. 2.1 Ga: such an increase secms unlikely. Thus the metasediments are probably younger than most of the orthogneisses.

\section{The Ammassalik Intrusive Complex}

The AIC has been dated at $1886 \pm 2 \mathrm{Ma}$ by the U-Pb method on zircons (Hansen \& Kalsheek, this volume). Another sample from the quarry at Ammassalik has a $2.32 \mathrm{Ga} \mathrm{T}_{\text {DM }}$ model age. This implies a significant role for ancient crustal sources in the petrogenesis of the AIC, but it is not yet possible to determine either the necessary involvement or the relative contributions of
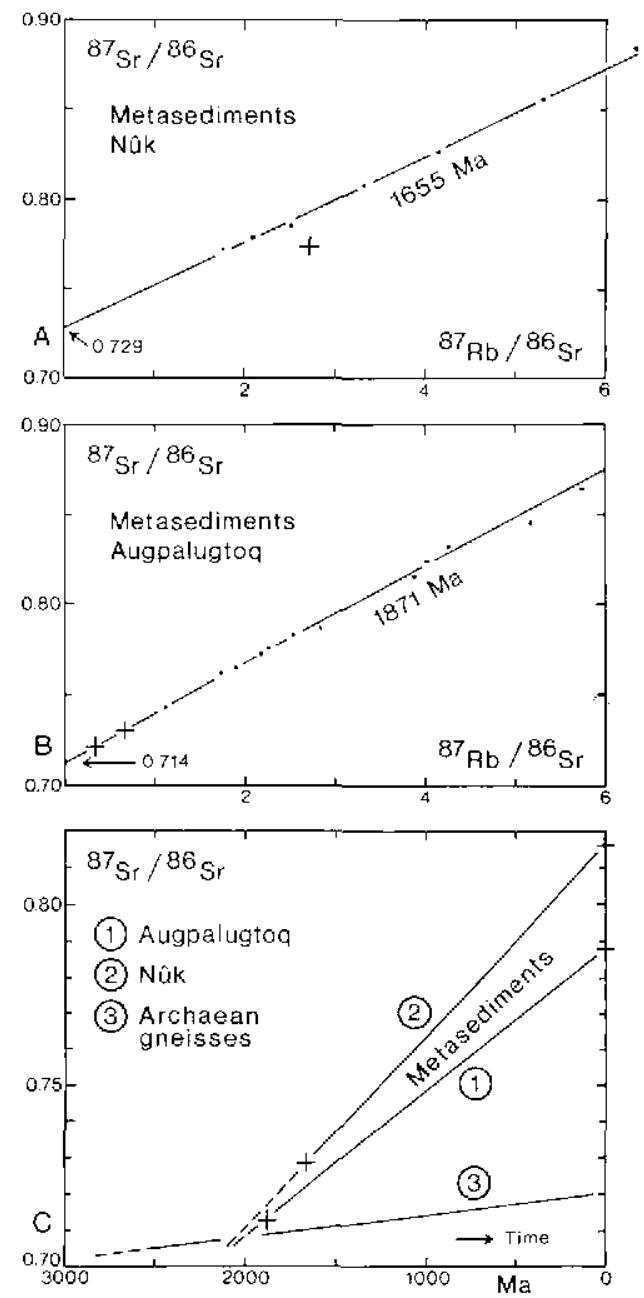

Fig. $2 \mathrm{~A}$ and B: Rb-Sr isochron diagrams for metasediments from Nûk and Augpalugtoq. The sample indicated by a cross in fig. 2A does not belong to the normal metasedimentary sequence (see the text). The samples shown by crosses in fig. $2 B$ are garnet-rich paragneisses with chemical compositions different from the other samples. Fig. 2C. illustrates the increase in mcan ${ }^{\mathrm{K}} \mathrm{Sr} / \mathrm{s}$ "Sr with time for the metasediments (calculated from their mean ${ }^{2 ?} \mathrm{Rb} /{ }^{\text {tht }} \mathrm{S}$ r ratios), compared with the Sr-evolution line for average Archaean gneisses in the region. The diagram demonstrates that, provided the ${ }^{87} \mathrm{Rb} /{ }^{k i} \mathrm{~S}_{\mathrm{r}}$ ratios of the samples did not change radically during metamorphism, deposition of the sediments cannot have taken place long before $c$. $2100) \mathrm{Ma}$.

Archaean basement in the Ammassalik area or early Proterozoic crustal sources or c. 1885 Ma mantle-derived material.

\section{Age of metamorphism}

Emplacement of the Ammassalik Intrusive Complex at c. $1885 \mathrm{Ma}$ is believed to post-date the peak of 
metamorphism in the vicinity of Ammassalik (Nutman \& Friend, this volume). Sm-Nd isotopic data for the garnet, clinopyroxene and whole-rock sample of an eclogite dyke at $65^{\circ} 44^{\prime} \mathrm{N}, 36^{\circ} 57.5^{\prime} \mathrm{W}$ (fig. 1, locality E) define an isochron (MSWD 0.28) yielding an age of $1817 \pm 22 \mathrm{Ma}$. $\mathrm{The} \mathrm{Pb} / \mathrm{Pb}$ whole-rock isochron for the suite of marbles from near the head of Sermilik yields a date of $1773 \pm 22 \mathrm{Ma}$. From studies in the Proterozoic mobile belts of West Greenland, it appears that $\mathrm{Pb} / \mathrm{Pb}$ isochron dates for marbles equate with metamorphic recrystallization ages. The other metasediments give $\mathrm{Rb}$-Sr whole-rock dates of $1871 \pm 50 \mathrm{Ma}$ (Augpalugtoq) and $1655 \pm 86 \mathrm{Ma}$ (Nûk).

Clearly there are disparities between some of these estimates of the age of metamorphism in the Ammassalik region. The age relations between the AIC and the metamorphism of the eclogite dyke are particularly difficult to reconcile. The eclogite dyke records a significantly younger $1817 \pm 22$ Ma metamorphic age than the emplacement of the supposedly post-metamorphic AIC at $1885 \mathrm{Ma}$. The metamorphic recrystallisation of the marble unit north of Sermilik is apparently a still younger event. The Rb-Sr date of $1871 \pm 50 \mathrm{Ma}$ for the Augpalugtoq metasediments may be consistent with either the AIC date or the eclogite dyke date (but not with both). The $1655 \pm 86 \mathrm{Ma}$ date for the Nûk metasediments conceivably reflects resetting of the $\mathrm{Rb}-\mathrm{Sr}$ system in pelitic lithologies (in which $\mathrm{Sr}$ is effectively an incompatible element) in response to emplacement of the post-tectonic intrusive suite at c. $1580 \mathrm{Ma}$.

\section{Discussion}

From these preliminary investigations, the main conclusions can be summarised as follows:

(1) Whereas in the areas to the north and south of the Ammassalik region Archaean $\mathrm{T}_{\mathrm{DM}}$ model ages are ubiquitous, within the Ammassalik region new material was added to the crust during early to mid-Proterozoic times: this is documented by the early Proterozoic $T_{D M}$ model ages of grey gneisses and tonalites at Síportôq and Tasilârtik, and of the Ammassalik Intrusive Complex.

(2) Metasediments in the Ammassalik region were derived from Archaean sources (Archaean $\mathrm{T}_{\mathrm{DM}}$ ), but consideration of their $\mathrm{Sr}$-isotopic evolution strongly favours deposition later than $c .2 .1 \mathrm{Ga}$, later than most of the orthogneisses in the region.
(3) The history of Proterozoic metamorphism in the Ammassalik region appears to be long and complex, commencing prior to the emplacement of the Ammassalik Intrusive Complex at $1886 \pm 2 \mathrm{Ma}$, and continuing until at least $1773 \pm 22 \mathrm{Ma}$. Further complications are associated with emplacement of the post-tectonic intrusive suite at $c .1580 \mathrm{Ma}$.

The occurrence of early Proterozoic grey gneisses and tonalites representing new crust formation within the Ammassalik mobile belt recalls the situation in the Nagssugtoqidian mobile belt of West Greenland (Kalsbeek et al., 1987). If these new crustal contributions represent subduction-related magmatic rocks it could signify that the Ammassalik region, like the Nagssugtoqidian mobile belt, includes a suture between two Archaean continental blocks. Several features of the Ammassalik mobile belt can be understood within the framework of a continental collision model:

(a) The mobile belt consists of a series of northwarddipping nappes and thrust sheets. On each side of the mobile belt is a wide border zone within which the Archaean crust has been subjected to Proterozoic deformation and thermal disturbance. This regional structure is consistent with the thrusting of a northern over a southern continental block. The occurrence of the eclogitic dykes in the area implies that some of the thrust sheets originate from very deep levels of the crust.

(b) Proterozoic supracrustal units in the Ammassalik region are dominated by metasedimentary lithologies with detrital components derived from Archaean crustal sources. These units are much more prominent within the mobile belt than in the areas to the north and south. They may represent continental margin deposits which were later involved in the collision event.

(c) Collision of continental blocks to produce tectonically over-thickened crust gives rise to a long-lived perturbation in the geothermal gradient which may take several tens of millions of years to decay. The apparently protracted history of Proterozoic metamorphism in the Ammassalik area may reflect the time taken to establish an equilibrium geothermal gradient through thick crust after such a collision-induced perturbation. Variations in the apparent ages of metamorphism within the mobile belt probably reflect real differences in the time of closure of parent-daughter isotopic systems in the dated rock-units, depending on rock-type and structural position within the tectonically thickened crust. 